\title{
はじめての
}

\section{精密工学 はじめての不確かさ}

\author{
Introduction to the Uncertainty in Measurement/Hideyuki TANAKA
}

(独) 産業技術総合研究所 計測標準研究部門 物性統計科 応用統計研究室 田中秀幸

\section{1. はじめに}

近年, トレーサビリティの確保・ISO/IEC 17025「試験 所及び校正機関の能力に関する一般要求事項」等に準拠し た品質システムの構築が要求され，それに伴い測定におけ る不確かさ評価が重要視されるようになってきたが, 校 正・試験機関等では普及してきた不確かさもまだ一般には 広まっているとはいえない, しかしながら, 不確かさ評価 は計測結果のばらつきを評価する手段である。つまり不確 かさ評価を行えば, 測定結果のばらつきがどのような要因 によって引き起こされ，大きさがどのくらいになるかとい うことが明示される。この結果は, 校正・試験機関だけに 利用価值があるものではない，つまり，一般企業で行われ る測定・大学等で行われる研究における測定でも有効利用 でき,さらにばらつきを求めるための考え方・手法は, 不 確かさの評価だけではなく, 測定すべてに適用できる普遍 的なものである.

本解説では, 従来の不確かさの解説のように, 不確かさ の算出法に関する統計的な手法を解説するのではなく, 不 確かさとはいったい何であるのか, という考え方や, 不確 かさにまつわる話を中心にした一般の測定・実験でも考慮 すべき基礎について解説したいと思う.

\section{2. 測定值を疑え}

最近ある熟練した測定者から言われたことがある。

「若い人は，測定を行ったとき測定值に表示された結果を 鵜吞みにする傾向がある。これは，ディジタル表示の計測 器のせいではないか？」

確かに，昔の測定器は指示計器を用いていたので，ある 程度以上の精度では值を決定することができない，との認 識を直感的に得ることができるが, ディジタル表示ではあ る值が最小表示桁まで確定的に出てきてしまう.

しかし，デイジタル表示された值も実際は確定值ではな く，ある時間内で積分された平均值であったり，あるサン プリング間隔で取得したデー夕をそのまま表示したもので あったりする。よって，表示值は測定の真值などを表した ものではなく，不確かさを含んだものである，という認識 を強く持つ必要がある.

このような認識を持たない人は，測定結果を非常に多く の桁数で報告する傾向がある。例えば, 測定結果を報告す
るとき,

$37.43547545359 \mathrm{~mm}$

等とするような場合である。これは極端な例であるが, 次 のような例ではどうだろう。表 1 に，ある繰返し測定に おける個々の測定值とその平均值を示す.

この例では, 個々の測定值と平均值との桁数は等しい (平均值は個々の測定值より一桁多く表示するときもある が，今回は個々の測定值の桁数に揃えた）。別にこれで問 題ないように思えるが，よく個々の測定值を見てみると， 一致している桁は, 小数点第 2 位までであり, それ以降の 值は一致していない。つまり，ここまで測定值がばらつい ているのであれば，下の方の桁はほとんど意味をもたな い.それどころか, ここまで桁数が多い場合には，コンピ ユータで標準偏差等の計算を行った際, 計算誤差を引き起 こす要因ともなる。よって, この測定結果は表 2 のよう に報告する方が望ましい.

さらに言えば, 計算を行うときには 1.32 の部分も除いた 方がよい. その方が, 計算誤差を引き起こさないですむ.

このようなことは, 測定值は不正確なものだ, という認識 があれば気がつくことができる、測定結果を評価するため には,まず測定值を疑うことから始めなければならない.

\section{3. ばらつきの要因}

不確かさ評価では，1）測定にばらつきを与える要因を ピックアップし，2）それぞれの要因によって引き起こさ れるばらつきの大きさを評価し，3）個々のばらつきを合 成し，4）測定結果のばらつきの大きさを算出する。ここ で, 一番大事なのが，1）測定のばらつきを与える要因を ピックアップすることである.

測定にばらつきを与える要因で一般的なものを次にあげ る.

表 1 ある繰返し測定の結果報告

\begin{tabular}{c|c|c|c|c}
\hline 1 回目 & 2 回目 & 3 回目 & 4 回目 & 平均值 \\
\hline 1.32456458 & 1.32573463 & 1.32376540 & 1.32634297 & 1.32510190 \\
\hline
\end{tabular}

表 2 訂正後の結果報告

\begin{tabular}{c|c|c|c|c}
\hline 1 回目 & 2 回目 & 3 回目 & 4 回目 & 平均值 \\
\hline 1.32456 & 1.32573 & 1.32377 & 1.32634 & 1.32510 \\
\hline
\end{tabular}


- 測定器

- 測定

- 測定対象

測定環境

測定器の要因は，その測定を行う装置そのものだけでは なく，前処理等を行う際に用いられる装置も含む。また校 正の際には用いた標準器の不確かさもここに含まれる.

測定の要因は, 測定の行為そのものから引き起こされる 要因で, 繰返し性, 再現性などが含まれる。

測定対象の要因は, 被測定物, つまり測定されるものが 原因のばらつきである。例えば，円柱の直径測定におい て，測定場所が異なることによるばらつきや，ロットが異 なることによるばらつきなどがある。そのほかにも，サン プリングによるばらつきもこれに含まれる。

測定環境の要因は，室温などである．

一般的にはこのような要因をピックアップし，ばらつき の評価を行うが，非常に気がつきにくい不確かさ要因がも う一つある。それは，「量の定義の不確かさ」である。

測定は，ある測定対象量の值を知るために行う。その測 定対象量にはその量の定義が存在する。そして，その量の 值を得るために測定方法が規定され，それに則って測定を 行うことによって, 測定量の值の推定值を得る。しかし, 量の定義が不完全であると，その不完全さが由来の不確か さが引き起こされる。

例えば，金属棒の長さの測定を行うことを考えたとき， その定義が「20ㄷのときの金属棒の長さ」であったとしよ

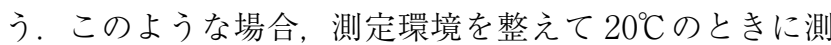
定を行うか, 温度を測定しながら長さの測定を行い, $20^{\circ} \mathrm{C}$ からのずれ分を補正すればよい. しかし，定義に「20ㄷ とき」というのがなければどうだろうか？このときは， 何 ${ }^{\circ}$ のときに測定を行えばよいのかが分からない.よっ て，測定時にあり得る温度変化分の金属棒の伸び縮みを不 確かさとして考慮する必要がある。

つまり，不確かさの要因を考えるときには，その量の定 義がどのようになっているかを考える必要がある。また， そこで大事なのは，量の定義がどのようなものであるか， ということだけでなく，量の定義によって決まっていない ものを考える必要がある。この決まっていないものが不確 かさの要因になる可能性がある.

例えば，規格等で測定器や測定するための施設の仕様が 決まっているときでも, 決められていなかった仕様が原因 で大きなばらつきを生じるときがある。試験所の試験結果 の妥当性を保証するために試験所間比較というものを行う ときがある。これは，ある一つの測定対象物を様々な試験 所が測定し，その結果を比べあうというものだが，全参加 試験所がある規格に則って，同じ測定手順で測定を行って も，測定結果が異なる場合がある。これは参加試験所の能 力が原因であることもあるが，量の定義の不確かさが原因 であるときも多い.

不確かさ要因をピックアップするときにもう一つ重要な
のが，測定結果に与える影響が大きい要因だけを抜き出す ことである，不確かさは二乗和の平方根によって合成され る.よって, 測定結果に与える影響が大きな要因と比べ相 対的に小さな要因はほとんど影響しない。例えば，二つの 不確かさ要因があり，それぞれの不確かさの大きさが，1 と 0.1 であるとすると，これらを合成した結果は，

$$
\sqrt{1^{2}+0.1^{2}}=1.0049 \cdots
$$

となる。最終的に報告する不確かさは原則 2 桁となってい るので，小さな要因は全く影響しないということが分かる であろう。

またこのことは，製造や測定のばらつきの低減にもいえ ることである。つまり，ばらつきを低減させるためにばら つきの小さな要因をつぶしてもほとんど意味がない.ばら つきを低減させるためには，一番大きなばらつきの要因を つぶさなければほとんど意味がない。この一番大きなばら つきを知るためにも不確かさ評価は有用である。

\section{4. 実験計画について}

不確かさの要因が決まれば, 次はその要因によって引き 起こされるばらつきを評価する。不確かさ評価では, 実際 に測定を行ってばらつきを推定する A タイプの評価法と， それ以外の手法である B 夕イプの評価法があるが，ここ では，実際に測定を行ってばらつきを評価する A タイプ の評価のことを考えよう.

最初に必ず行わなければならないことは，何を評価した いのか，という測定目的の明確化である。つまり，不確か さ評価の場合であれば, 評価したいと思っているばらつき を明確化することである。

次は，そのばらつきを評価するための実験を計画する必 要がある。しかしながら，この実験を計画するというとこ ろがいい加減な場合が非常に多い。よくあるのが，とりあ えず測定を行って，その後でどのようにデータ処理をすれ ばよいのか，ということを考えることである．

例えば次のような事例を考えてみよう。

例：ある部品の製造装置を購入したい。その製造装置には $\mathrm{A}$ 社製のものと $\mathrm{B}$ 社製のものがある。よって, その装置 を借りて製品サンプルを制作し，そのサンプルを比較する ことによって，どちらを購入するかを決めたい。製品サン プルを 1 つ作成するには半日かかり，製造装置は 1 週間借 りるものとする

このような条件では多くの人は次のような順番で実験を 行う。表 3 にその実験の順番を示す.

別に何の問題もない実験だと思われるが，しかし，この ような実験は一番やってはいけない実験である.

前提条件を思い出してみよう。1 週間装置を借りる。1 つのサンプルを製造するのに半日かかる。もし月曜日の朝 から実験を行ったとすると，表 4 に示すような実験のス ケジュールが決まる.

表 4 を見ると, 装置 A でサンプルを製造するのはすべ て午前中であり, 装置 B ではすべて午後となる。もしこ 
表 3 実験の順番

\begin{tabular}{c|c|c|c|c|c}
\hline 装置 A & $(1)$ & $(3)$ & $(5)$ & $(7)$ & $(9)$ \\
\hline 装置 B & $(2)$ & $(4)$ & $(6)$ & $(8)$ & $(10)$ \\
\hline
\end{tabular}

表 4 実験のスケジュール

\begin{tabular}{c|c|c|c|c|c}
\hline 装置 $\mathrm{A}$ & 月午前 & 火午前 & 水午前 & 木午前 & 金午前 \\
\hline 装置 B & 月午後 & 火午後 & 水午後 & 木午後 & 金午後 \\
\hline
\end{tabular}

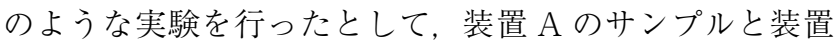
B のサンプルが異なっていたとしても，これは，装置 $\mathrm{A}$, B が異なることによって現れた差なのか，それとも午前・ 午後に製造したということが理由で現れた差なのかが区別 できない。これでは何のために実験を行ったのかが分から ない．このようなデー夕を得た後で，午前・午後に製造し たということが理由の変動と, 装置 A・Bによる変動とを 分離したいと思っても不可能である。つまり，実験デー夕 を得た後にデー夕処理方法を考えても手遅れなのである. 筆者の元にもよく不確かさ評価法についての相談がくる が，たまにこのような「手遅れ」の相談がされることがあ る。デー夕を取得した後ではなく、デー夕を取得するため の実験計画から相談してもらえればよかったということで ある。

この例の場合では,「実験のランダム化」という手法を行 えばよい. 実験のランダム化とは, 実験を行う順番をランダ ムにする,ということである.今回の例の場合では, 表 3 で 示した順番ではなく,装置 $\mathrm{A} \cdot \mathrm{B}$ のどちらでサンプルを製造 するか, という順番をさいころや, 乱数表を用いてランダム に行う,ということである。皇の一例を表 5 に示す。

このような順番で行えば, 装置 $\mathrm{A} も$ 装置 $\mathrm{B}$ も午前・午 後両方でサンプルを製造することになり，純粋に装置 A と装置 Bで作成されたサンプルを比較することができる. この実験のランダム化は不確かさ評価だけではなくほとん どの実験に適用できる手法である。

このように実験の計画は安易に考えられがちであるが, 実験を行う際の最も重要な要素の一つである，実験計画法 という手法が品質管理でよく用いられる。しかし，この実 験計画法は分散分析等の統計的な側面に注目が集まりがち なのであるが，一番重要なのは，「実験するときには計画 を立てる」ということである.

\section{5. ばらつきの推定}

不確かさ評価では，測定のばらつきを標準偏差を用いて 表すが，その推定された標準偏差はどのくらい信頼がもて るものなのであろうか?

不確かさの算出法を規定した「計測における不確かさの 表現のガイド」(原題:Guide to the Expression of Uncertainty in Measurement, 略称: GUM ${ }^{1)}$ の付属書 $\mathrm{E} に$ 「不確かさの不確かさ」についての記述がある。「不確かさの 不確かさ」とは, 推定された不確かさ, 詳しくいうと $n$ 個の
表 5 ランダム化された実験の順番

\begin{tabular}{c|c|c|c|c|c}
\hline 装置 A & $(1)$ & $(2)$ & $(4)$ & $(5)$ & $(8)$ \\
\hline 装置 B & $(3)$ & $(6)$ & $(7)$ & $(9)$ & $(10)$ \\
\hline
\end{tabular}

表 6 不確かさの不確かさ

\begin{tabular}{c|c}
\hline 観測值の数 $n$ & 不確かさの不確かさ $(\%)$ \\
\hline 2 & 76 \\
\hline 3 & 52 \\
\hline 4 & 42 \\
\hline 5 & 36 \\
\hline 10 & 24 \\
\hline 20 & 16 \\
\hline 30 & 13 \\
\hline 50 & 10 \\
\hline
\end{tabular}

データから推定された標準偏差が, 真の標準偏差 (母標準偏 差)に比べどの程度変動するのか, ということを表した指標 である.ここで, GUM 付属書 $\mathrm{E}$ 内の「表 E. 1 正規分布に従 う確率変数 $q$ の独立な $n$ 個の観測值の平均 $\bar{q}$ の実験標準 偏差の, その平均の標準偏差に対する比」を本解説「表 6: 不 確かさの不確かさ」として引用する。

表 6 を見て分かるように, 標準偏差の推定精度は非常に 低い。たとえ50回の繰返し測定を行って標準偏差を推定 しても，母標準偏差と比べて $10 \%$ 值が変化するというこ とが起こっても全く不思議ではない.つまり基本的に, 標 準偏差は最初の一桁は信頼できても，二桁目は怪しくなっ てくる．3．ばらつきの要因，でも少しふれたが，不確か さを報告するときは原則 2 桁となっているのは， 2 桁目も 怪しいので，3桁目など全く信頼できない，というところ からきている。これについてはGUMにも, 最終的に報告 する不確かさはよけいな桁数を与えない方がよい, 多くと も 2 枌の有効数字で十分である, という旨が記載されてい る.

よって, 同様の測定を行った際の不確かさを評価した結 果が，異なっていたとしてもそれは当たり前のことであ る. また, 評価された不確かさが有効数字の 2 桁目で片方 の不確かさがもう片方より 3，4 位小さかったとしても， 実際に不確かさが小さいとはいえない，その程度であれ ば，同等であると見なすべきであろう，わずかな不確かさ の大小で一喜一憂することはナンセンスである.

\section{6.「不確かさ」の真の意味とは}

不確かさという用語は近年よく使われ始めてきている が，その不確かさの意味を誤解している人は多い。一番多 いパターンは,「マイクロメータの不確かさ」という言葉 に代表される誤解である。

不確かさの定義は,「測定の結果に付随した，合理的に 測定量に結びつけられ得る值のばらつきを特徴づけるパラ メー夕」である。ここで注目してほしいのは,「測定の結 果に付随した」という部分である。

つまり，不確かさとは，「測定の結果に付随」するもの 
であって,「測定器に付随」するものではないということ である，不確かさとは測定の結果に付随するので，測定器 のみではばらつきを評価することはできない，これは例え ば，ノギスで金属板の厚さを測定したときのばらつきと同 じノギスで豆腐の厚さを測ったときでは，測定のばらつき が異なるのは当然である。つまり，何を測定するのか，と いう測定対象物が決定しない限り，測定結果のばらつきは 評価できない，ということである。

しかし，「マイクロメータの不確かさ」というような, いかにも不確かさが装置に付随しているということをイメ ージさせる言い方は一般的によくされている。これは, 「マイクロメータの校正の不確かさ」のことを短縮して言 っているのである.

では，「校正の不確かさ」とは何なのであろうか．マイ クロメータを例にとって言うと，マイクロメータは，ブロ ックゲージを用いて校正される。校正という作業は，標準 器を用いて, 被校正物に值付けを行う作業のことである. つまり，校正の不確かさとは，標準器によって被校正物に 值付けしたその值の不確かさのことである。よって，校正 の不確かさも測定結果に付随した不確かさの一つといえ る.

次に不確かさの定義内の「ばらつきを特徵づけるパラメ 一夕」という部分を見てみよう，不確かさは測定のばらつ きを表すが，それには裏の意味がある。つまり，「かたよ りが分かっているのであれば，そのかたよりは補正して， その補正後のばらつきを評価する」ということである.

しかし，不確かさではかたよりを全く扱わない，という わけではない，不確かさでは「未知のかたより」を「ばら つき」として扱う。この典型的な例は，デイジタル表示に 起因する不確かさである。例えば，電圧を測定した結果 が，2.3Vであったとしょう。この電圧計の最小表示椼は $0.1 \mathrm{~V}$ である. よって, $2.3 \mathrm{~V}$ と表示されていても，この值 は $2.25 \mathrm{~V} \sim 2.35 \mathrm{~V}$ の間に存在している，ということだけし か言えない，不確かさではこの $2.25 \mathrm{~V} \sim 2.35 \mathrm{~V}$ で值がばら ついている，と考えて評価を行うが，実はこれは未知のか たよりを扱っているのである。つまり，2.25 V〜2.35 V 内 のどこかには真の電圧が存在している（本来であれば, $2.25 \mathrm{~V} \sim 2.35 \mathrm{~V}$ 内に真の電圧が存在するという保証は全く ないが,ここでは便宜的に真の電圧という言葉を用いる). これは，2.3Vからのかたよりである（図1）。しかし，そ のかたよりの大きさは現在持っている情報だけでは全く知 ることができないので，これはばらつきと同じ性質をも つ。つまり，不確かさとは測定のばらつきと未知のかたよ りを扱うパラメータなのである。

\section{7.おわりに}

ここまで本解説は不確かさとは何か，また不確かさに関 する周辺の話を行ってきた。ここでは，結びの言葉の代わ

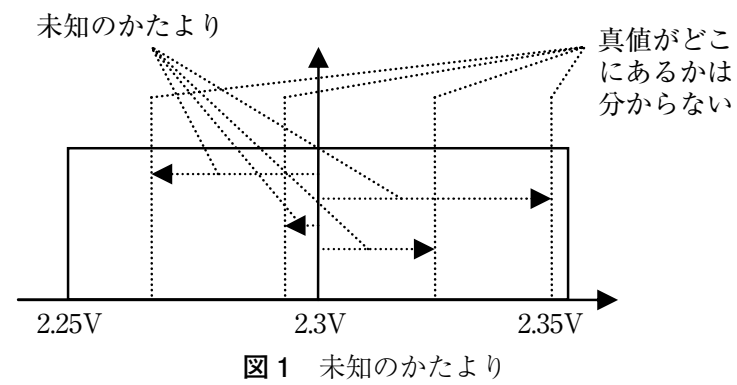

りとして, さらに不確かさに関して調べてみたい人のため に参考文献を紹介したいと思う。

・計測における不確かさの表現のガイド1

これは，不確かさ評価に扔けるバイブルである，不確か さを評価する人は GUM を持っているべきである。しかし ながら, 不確かさの初心者がGUM を用いて不確かさを学 習するのは，慣れ親しんでいない統計に関する記述故に非 常に困難である，学習する場合には以下にあげる解説を用 いた方がよい，しかしながら GUM は非常に注意深くかか れた文書であり，実に細かなところまで記述されている． よって，不確かさを他の本などを用いて学習した人が，実 際に不確かさ評価を行ったときに他の本に書かれていなか ったことに直面したときに，GUM にそのことに関する記 載がないかを辞書のように用いて調べるとよい。ほとんど のことは GUM に記載されている。

·(独)製品評価技術基盤機構 $\mathrm{HP}^{2}$

HP 内適合性認定分野のページには, JCSS, JNLA とい ったISO/IEC 17025 の認定プログラムに関する情報が載 っている，その中でも公開文書一覧には，「測定の不確か さに関する入門ガイド」「校正の不確かさに関する表現」 と各量の不確かさの見積もりの事例が公開されている。 ま た，JNLAのほうの公開文書には，校正ではなく，試験に おける不確かさの評価事例が公開されている.

・不確かさ $\mathrm{Web}^{3)}$

筆者が所属する応用統計研究室が運営する HP で, 当研 究室と日本電気計器検定所が共同で開発した初心者用不確 かさセミナーテキストの半分がダウンロードできる.

·日本電気計器検定所 $\mathrm{HP}^{4)}$

初心者用不確かさセミナーテキストの残り半分がダウン ロードできる.

これらの文書類を有効利用し, 不確かさへの理解を深 め, 不確かさを有効に利用してほしい.

\section{参 考 文 献}

1）監修 飯塚幸三：計測における不確かさの表現のガイド，日本規 格協会，第 1 版，(1996).

2) http://www.nite.go.jp

3) http://www.nmij.jp/stats-partcl/uncertainty/uncertainty.html

4) http://www.jemic.go.jp/ 